\title{
Dynamics of a knowledge economy: introduction
}

\section{Wilfred Dolfsma and Luc Soete}

Some commentators believe the term knowledge economy to be too elusive to be useful. Others have found the idea of knowledge, information and abilities as being prime resources for economies to be very valuable. It is fair to say that any assessment of the contemporary role of knowledge must recognize that most economic activity rests on knowledge, not only in present society but in all forms of human society. Palaeolithic society was by any standards 'knowledge-based', and palaeontologists have demonstrated the existence of well-formed bodies of knowledge with respect to animal behaviour, materials, mining, symbolic communication and even medicine. In the more recent past, the industrial economy of the nineteenth century was intensively knowledge-based. At first sight many claims about the current 'knowledge economy' could plausibly have been made a hundred years ago. It is of course true that knowledge accumulates over time, that it changes the quality and quantity of output. Hence that today the knowledge intensity of production is likely to be much higher than ever before. But does this obvious point mean we are entering some new form of society, which is qualitatively different in terms of the use of knowledge?

There is obviously a clear impression that rates of change seem to have increased in the last three decades, at least as appears from the discussions among economists and social scientists. Since Foray and Lundvall (1996), Cowan et al. (2000) and Cooke (2002), much has been said about the knowledge economy or the knowledge base of the economy. Foray (2004) presents a recent overview. As a typical measure of just how much has been said about the term, entering it in the quintessential Internet search engine Google provides one with some 637000 hits (22 August 2005). This web search only took 0.19 seconds. 


\section{A DYNAMIC KNOWLEDGE ECONOMY}

Much previous research can perhaps be reinterpreted as analysing the role of knowledge in the economy, and the knowledge economy. The economic development of regions was perceived by Alfred Marshall as dependent on knowledge and ideas that are 'in the air'. Later scholars have called such phenomena externalities or knowledge externalities. Romer (1986, 1993) and more recently Baumol (2002) have both made this case. Attention has focused on, for instance in the field of economic geography, growth poles (Perroux, 1955), learning regions (Morgan, 1997), national or regional innovation systems (Nelson, 1993; Bradzych et al., 1998), and innovative milieu (Camagni, 1995). Diffusion of knowledge and information in geographically restricted areas is relatively fast: circulation, imitation and cooperation is enhanced (compare Saxenian, 1994). There is debate about the nature of the knowledge and information that should be circulating within the bounds analysed: should it be of a highly specialized or of a more diverse nature (van der Panne, 2004)? Sometimes it seems as if the terms in which the discussion is phrased are recast in terms of the knowledge economy (for example, Werker and Athreye, 2004). Turning to a discussion of knowledge's role in the economy is, thus, not new. ICT as both source and medium for knowledge to accumulate and diffuse at the micro level of firms, groups or communities, as well as at the macro level within countries and at a global level did, however, add a particularly acute sense of urgency to the discussion (compare Ter Weel and Soete, 2005).

Whatever one may think of the term, it is clear that developments in our current economy are related to 'knowledge' and noteworthy for their dynamics. Not only do developments seem to have speeded up over recent years and decades, but the complexity of their dynamics seems to have increased. Discussing the role of knowledge in the economy poses fundamental theoretical problems. The conceptualization of information, the individual and how he/she acquires knowledge, as well as his/her interaction with other agents are implicated (Davis, 2003; Dolfsma, 2001). Such a discussion also impacts views on how society is to be institutionally furnished - a realization that first dawned, perhaps, with Hayek (1945).

\section{THIS VOLUME}

This volume does not offer ready-made answers to whatever questions one might have about the knowledge economy, as an academic, as someone responsible for making (government) policy, as an entrepreneur, or as a citizen. That is a strong point of this volume, we believe, as it would seriously 
jeopardize the tenability of what is offered here had we succumbed to the temptation of attempting to offer such answers. The dynamics of the knowledge economy would soon render obsolete whatever concrete answers would be offered that would be readily usable. Instead, what is offered here are views of the knowledge economy that contribute to a better understanding of what is going on. These views allow us to 'read', so to speak, the knowledge economy. The views may be views on macro themes such as the ones offered by Mokyr and Leydesdorff, but others are of a more micro nature. Joel Mokyr, in Chapter 1, extends his previous work on the Industrial Revolution, answering the questions of why it arose, when and where it arose, by turning to the role of ideas and practices one associates with the Enlightenment. According to him, these offer an important element that is needed to explain the extraordinary events of the Industrial Revolution. For all that is said about the knowledge economy, at least by some, the comparison would seem to be appropriate. Even if the two are incomparable phenomena, the act of comparing would allow one to realize that ideas play a powerful role in the economy; their relatively unencumbered circulation is ultimately likely to be beneficial to the economy as well. Circulation of ideas just for the sake of circulation does not make much sense, and there should thus be institutions that not only help circulate ideas, but also sift them (compare Mokyr, 2002).

Loet Leydesdorff offers the theoretical foundations to rebut all those who have criticized the term 'knowledge economy' as elusive, or worse. He draws on information theory, systems theory, and scientometrics to argue that the knowledge base of an economy can be grasped theoretically. In subsequent work (Leydesdorff et al., 2006) the knowledge base was grasped empirically as well, with some noteworthy findings as to the origins of contributions to it. Leydesdorff argues that knowledge and information are exchanged when players in a relatively confined context interact, thereby shaping each others expectations. Coming from a different theoretical background, but nevertheless focusing on that same theme, Nathalie Lazaric and Catherine Thomas present their analysis of just such interactions for a specific region in France that is noteworthy for its economic dynamics: the Sophipolitan telecom cluster. Needless to say, the theoretical framework is much more focused on the micro level, relying on concepts such as routines, rules and knowledge (codification). Specific actors can and do have an influence on the development of a region (see also, for example, Lawson, 2003). Erik Stam and Elizabeth Garnsey, much in line with the theoretical approach adopted by Lazaric and Thomas, study a different phenomenon. Their focus is on the trajectories that newly established firms may go through, trying to establish regularities. Using Edith Penrose's (1995) concept of an opportunity environment, they claim that 
the growth of firms needs a closer look than tends to be done usually in order to find out what might facilitate or hinder it. At an even more micro level of interactions between individuals, yet at the same time concerning a phenomenon that stretches across the boundaries of organizations and firms, Paul Muller analyses the dynamics within groups informally cooperating, in this case, to develop open source software. He shows what explains the informal structures establishing reputation and leadership that emerge in such groups, and how that influences both the process as well as the outcome of cooperative efforts.

Both Theo Dunnewijk and René Wintjes (Chapter 6) and Isabel Salavisa (Chapter 7) zoom in on the state. Wintjes and Dunnewijk make a more down to earth case about the role of the state in Flanders (Belgium). Here, the state has played a much more active role than is sometimes suggested is appropriate for a state in a globalized, ICT-driven knowledge economy. Such an active involvement it is often argued, is doomed to fail. Wintjes and Dunnewijk show that this need not be the case - there is rather a need for sustained commitment from the state, but, obviously, no guarantee for ultimate success. Isabel Salavisa takes the discussion about the role of the state to a more general level. She argues that one should not expect a reduced role of the state in a complex knowledge economy. Indeed, as society and the economy have become increasingly complex over the last century and more, the state has only grown, despite efforts, on and off, to diminish its role. However, when contemplating measures, a government is in need of some framework that might help it decide in which areas to institute, change or remove what kind of regulations. Chapter 8 , by Wilfred Dolfsma, suggests that due to the nature of knowledge and knowledge development, this cannot be the usual measuring rod of Paretian welfare theory provided by economists. He argues that at least the Paretian framework should be complemented with consideration from what he calls a dynamic welfare theory. From such a dynamic (Schumpeterian) welfare perspective, Dolfsma evaluates current developments of an institution that is crucial for the knowledge economy: intellectual property rights.

Rather than starting this volume on the knowledge economy with a contribution about the concept of knowledge itself, the editors have decided to postpone the extensive exploration of that concept to the end of the book. Jorge Bateira offers a profound conceptual analysis of the concept of knowledge. One that is not the common position to take in economics (compare Dolfsma, 2001), but one which finds much support in other social sciences besides economics, and one to which at least the more sensible economists are moving (Nelson and Nelson, 2002). Had the editors started the volume with a contribution defining, or at least extensively discussing, the concept of knowledge, there would be a need to indicate the extents to 
which the subsequent contributions adhere to such a view. That might have distracted from the main argument of the book - to offer a range of views to read the knowledge economy - and might even have prevented us from offering a wide range of possible readings of the knowledge economy as the focus of chapters. A discussion in each chapter of the extent to which the views on knowledge assumed align with those of others might prevent contributors from arguing their case.

This last consideration has also made the editors decide not to offer concluding remarks. We are under no illusion that the different understandings provided can be synthesized easily and concisely. What is more, and even if that would entail a prolonged discussion, we believe we would be doing the readers of this volume a disservice by attempting to offer such concluding remarks.

\section{REFERENCES}

Baumol, W.J. (2002), The Free-market Innovation Machine: Analyzing the Growth Miracle of Capitalism, Princeton, NJ: Princeton University Press.

Bradzych, H.J., P. Cooke and M. Heidenreich (eds) (1998), Regional Innovation Systems, London: UCL Press.

Camagni, R.P. (1995), 'The Concept of Innovative Milieu and its Relevance for Public Policies in European Lagging Regions', Papers in Regional Science, 74(4): 317-40.

Cooke, P. (2002), Knowledge Economies, London: Routledge.

Cowan, R., P. David and D. Foray (2000), 'The Explicit Economics of Knowledge Codification and Tacitness', Industrial Change and Corporate Change, 9(2): 211-53.

Davis, J. (2003), The Theory of the Individual in Economics, London: Routledge.

Dolfsma, W. (2001), 'Metaphors of Knowledge in Economics', Review of Social Economy, 59(1): 71-91.

Foray, D. (2004), The Economics of Knowledge, Cambridge, MA: MIT Press.

Foray, D., and B.-A. Lundvall (1996), 'The Knowledge-based Economy: From the Economics of Knowledge to the Learning Economy', in OECD Documents: Employment and Growth in the Knowledge-based Economy, Paris: OECD, pp. $11-32$.

Hayek, F. (1945), 'The Use of Knowledge in Society', American Economic Review, 35(4): 519-30.

Lawson, C. (2003), 'Technical Consultancies and Regional Competences', in W. Dolfsma and C. Dannreuther (eds), Globalization, Social Capital and Inequality, Cheltenham, UK and Northampton, MA, USA: Edward Elgar, pp. $75-92$.

Leydesdorff, L., W. Dolfsma and G. van der Panne (2006), 'Measuring the Knowledge Base of an Economy in terms of Triple-helix Relations among "Technology, Organization, and Territory" ', Research Policy, 35(2).

Mokyr, J. (2002), The Gifts of Athena - Historical Origins of the Knowledge Economy, Princeton, NJ: Princeton University Press. 
Morgan, K. (1997), 'The Learning Region: Institutions, Innovation and Regional Renewal', Regional Studies, 31(5): 491-503.

Nelson, R.R. (ed.) (1993), National Innovation Systems: A Comparative Study, Oxford and New York: Oxford University Press.

Nelson, K. and R.R. Nelson (2002), 'On the Nature and Evolution of Human Know-how', Research Policy, 31: 719-33.

Van der Panne, G. (2004), 'Agglomeration Externalities: Marshall versus Jacobs', Journal of Evolutionary Economics, 14(5): 593-604.

Penrose, E.T. (1995), The Theory of the Growth of the Firm (first published 1959), Oxford: Oxford University Press.

Perroux, F. (1955), 'Note sure le Notion de Pôle de Croissance', Economie Appliqué, 7: 307-20.

Romer, P. (1986), 'Increasing Returns and Long-run Growth', Journal of Political Economy, 94: 1002-37.

Romer, P. (1993), 'Two Strategies for Economic Development: Using Ideas and Producing Ideas', Proceedings of the World Bank Annual Conference on Development Economics 1992, IBRD/World Bank.

Saxenian, A. (1994), Regional Advantage, Cambridge, MA: Harvard University Press.

Ter Weel, B. and L. Soete (eds) (2005), The Economy of the Digital Society, Cheltenham, UK and Northampton, MA, USA: Edward Elgar.

Werker, C. and S. Athreye (eds) (2004), Knowledge and Innovation Driving Regional Economic Development and Growth, special issue of the Journal of Evolutionary Economics, 14(5). 